\title{
DE BARRADO NA PORTA A CIDADÃO HONORÁRIO SOTEROPOLITANO
}

Nos anos da repressão da ditadura militar, a coragem e o discernimento do Pe. Cláudio inspirava a equipe de CEAS e seus simpatizantes nas regiões do Nordeste e do Brasil aí fora a criticar as arbitrariedades do regime militar e a refletir com liberdade singular sobre aquele momento histórico que o pais passava.

A repressão criava um ambiente de censura ao mesmo tempo em que mandava mensagens sobre fatos ocorridos que não eram para ser noticiados. Mas Pe. Cláudio e sua equipe sabiam julgar até onde podiam ir na publicação de matéria crítica do desenvolvimento "milagroso" que não era ordenado a uma profunda transformação social e uma justa distribuição da renda. Entre CEAS e o Governo, era um jogo fino. CEAS atuava com uma liberdade discreta. O fechamento da obra pelo governo ficava sempre uma possibilidade; mas a equipe sabia que isso iria embaraçar os governantes, que anunciavam uma abertura gradativa. Certamente pesava nesta avaliação do governo a opinião de que a revista CEAS era obra de um grupo de intelectuais em diálogo com outros intelectuais - além do alcance do povão. Assim, o governo tinha interesse em deixar CEAS funcionar. Com muita coragem, a equipe usava esta equação nos seus cálculos. Prosseguia com uma liberdade que poucos ousavam exercer na época - e que refletia a liberdade interior que era caraterística de Cláudio. Ou seja, embora muito modesto, o CEAS continuava a ser a voz de uma Igreja que apresentava as exigências da justiça social em defesa do povo mais explorado. Nas décadas da ditadura os Cadernos de CEAS se tornaram um ponto de referência para muitos Bispos e agentes pastorais do Nordeste.

Mas não só isso. Pois, o espírito de acolhimento do Pe. Cláudio fez com que a obra se tornasse um espaço hospitaleiro, tanto nas páginas da Revista, como no salão do CEAS e, quando for necessário, oferecia hospedagem na Comunidade de Jesuítas. Como Diretor do CEAS, Cláudio abriu o salão a um grupo intercolegial de estudantes da rede pública, que se reuniam lá cada Domingo para confraternização e Missa, durante doze anos. Ao mesmo tempo, com as incansáveis viagens dele e de outros membros da equipe, as iniciativas populares eram visitadas e fortalecidas, aonde fosse que se encontravam. 
O fato de CEAS estar em diálogo com pensamento esquerdista não foi aceito por muitos setores da sociedade baiana. Típica da reação destas pessoas era a carta publicada no Tribuna da Bahia, no 7 de abril de 1974, na qual o autor afirmava que o Pe. Cláudio Perani " se orgulha de não mais saber rezar missa, sendo que seu livro preferido é o Capita de Marx e Engels". Na verdade, o Pe. Cláudio foi o primeiro a sair da casa cedo diariamente, para celebrar Missa no convento das Mercês. Enquanto ao seu livro preferido, suas reflexões nas reuniões de Comunidade mostravam que refletia continuamente sobre os Evangelhos e os documentos da Igreja e da Companhia, dentro da realidade que vivíamos, e numa atitude de compaixão para os pequenos injustiçados.

O CEAS tinha o apoio do Dom Avelar Brandão, mesmo que, às vezes, Cardeal e CEAS tinham de deixar a poeira baixar para resolver problemas entre eles mesmos. Foi o caso quando a revista criticou a visita do Papa João Paulo II a Brasil. Entre Cláudio e o Cardeal, o respeito mútuo e a cordialidade sempre prevaleciam. Dois corações grandes!

O Pe Cláudio nunca deixou de amar Bahia, não obstante os "anos de chumbo" que tinha experimentado lá, inclusive uma tentativa do Governo de barrar sua entrada no Brasil, no retorno de uma visita à Itália. Dois policiais federais abordaram Cláudio enquanto esperava sua bagagem aparecer; anunciaram que ele tinha de ir com eles. Mas Claudio, com seu tamanho, os arrastou ao portão da área e gritou ao Provincial, Pe. Dionísio o que estava acontecendo. Dionisio invadiu o lugar exigindo uma explicação para o Cardeal. Então, com Cláudio se deitando nas costas em algumas cadeiras na sala VIP, os policiais exigiam do piloto do avião que o levasse de volta a Lisboa. Mas este recusava, afirmando que tinha cumprido a sua parte, levando-o de vinda a Salvador. Nestes entretempos, começaram a chegar ao aeroporto grupos de populares ligados ao CEAS. Mas já outros amigos tinham entrado em contato com pessoas conhecidas da alta escala do Governo, e Cláudio foi liberado. A respeito da experiência, Cláudio disse uma vez que a pior parte foi de ter de esperar até que outros resolvessem o seu caso. Quem conhecia a maneira decisiva dele assumir o protagonismo nas crises que surgiam, entenderia muito bem esta afirmação. '

Tal logo resumiu o seu trabalho no CEAS e no Sul da Bahia, com os canavieiros. No ano 1994, quando estava para sair de Bahia e assumir a sua nova missão de Superior do Distrito dos Jesuítas da Amazônia, o quase-exiliado Pe. Cláudio Perani, S.J., foi convocado pela Assembleia dos Vereadores de Salvador, que conferiu nele o título do qual sempre tinha muito orgulho: Cidadão Honorário Soteropolitano!" 
Pe. Ronaldo Colavecchio, SJ*

* Professor de Teologia e orientador de Exercícios Espirituais. 